\title{
Barriers to the upgrade cycle in a commodity process industry: Evidence from the UK packaging industry
}

Attempting to move away from commodity based products into higher value added ones remains one of the key challenges for R\&D Managers. This paper explores these challenges with evidence from a case study with a UK packaging manufacturer. The paper contributes to Lager (2000) and Lager \& Blanco's (2010) model of the product degradation-upgrade cycle. The paper presents the findings of a longitudinal three-year research project with one of the largest packaging manufacturers in Europe. Five barriers facing R\&D are identified when attempting to move away from commodity products.

Keywords: R\&D management, process innovation, absorptive capacity, packaging industry. 


\section{Author Biographical Details}

Christopher Don Simms (MA, University of Portsmouth) is a Senior Lecturer in Marketing and New Product Development. He is currently studying for a $\mathrm{PhD}$, which is examining the development of new packaging within the FMCG Industry. Address: Portsmouth Business School, University of Portsmouth, Richmond Building, Portland Street, Portsmouth PO1 3DE. [email: chris.simms@port.ac.uk]

Paul Trott (PhD, Cranfield University) is a Reader in Innovation Management at the University of Portsmouth, and is Professor of Innovation \& Entrepreneurship at Delft University of Technology, The Netherlands. Address: Portsmouth Business School, University of Portsmouth, Richmond Building, Portland Street, Portsmouth, PO1 3DE. [email: paul.trott@port.ac.uk] 


\section{Introduction}

The majority of studies on innovation have tended to focus on technology intensive industries, with lower technology industries (including process industries) receiving far less attention. Yet, within process industries, developing new and improved products with greater functional performance is essential for delivering improved margins and profitability (Reichstein and Salter, 2006; Leonard-Barton, 1992). The nature of process industries, and the associated importance of being cost-effective in production, forces $R \& D$ to look both ways in terms of delivering process innovation improvements and creating new product opportunities. This represents a dilemma for R\&D Management, for it creates a high level of pressure on $R \& D$ to provide evidence of its contribution (Lager \& Blanco, 2010). This article examines the R\&D challenges faced by one firm as it wrestles with innovating its product within a commodity process industry and provides insights into the issue of 'upgrading' to producing functional products (Linn, 1984; Lager, 2000; Lager \& Blanco, 2010).

Clearly the industrial context shapes decision-making and Porter's taxonomy of technology strategies illustrates this (Porter, 1985). In this framework, process innovation is often associated with the attempts of firms to achieve cost leadership in their market segment or to focus on cost reductions in the production of existing products. Consequently this is what we find in the packaging industry, which forms the focus of our study. The products it generates are generally commodities, with little in terms of functional differentiation, as is the case for the paperboard sector of the industry (this is reflected in Figure 3). However, for the primary customers of the packaging industry, packaging forms an integral part of their product offering (Simms \& Trott, 2010; Rundh, 2005) and packaging developments alone can be responsible for the success of products. For example, innovations in the beverages sector include 'Tetrapak', PET bottles and 'in-can' systems (e.g. the Guinness 'Widget'). 
This research represents part of a three-year project sponsored by Chesapeake, one of the largest paperboard ${ }^{1}$ packaging manufacturers in Europe. The aim of the paper is to examine the R\&D challenges and barriers involved in moving away from commodity based products and related activities into higher value added ones. Our findings contribute to existing theory by extending Lager (2000) and Lager \& Blanco's (2010) model of the 'upgrade-downgrade cycle'. We uncover five barriers that hinder firms attempting to increase the level of product differentiation in order to 'upgrade' (Linn, 1984; Lager, 2000), these include; the emergence of powerful buyers, the lack of internal packaging champions, and a language problem. The remainder of this paper is structured as follows, a brief review of theoretical and empirical work on $R \& D$ management with respect to process industries theory is provided. This is followed by a description of the study method, after which the findings are presented. Finally, this article discusses the implications of the results as well as limitations and possible directions for future research.

\section{Literature Review: Upgrade cycle and Innovation}

We have structured our review of previous research in three parts. We begin with an overview of the challenge facing process industries within the upgrade-downgrade cycle. We then examine two key themes within this field that influence this cycle: incremental innovation and the role of the supply chain.

\subsection{Process Industries: Commodity and functional products}

Process industries span a number of sectors (Lager \& Blanco, 2010), which can be divided into the following main groups: food, paper and cardboard, chemicals, raw oil, rubber and plastics, building materials, pottery and glass, primary metal, and energy (Koene, 1988).

\footnotetext{
${ }^{1}$ The packaging manufacturing industry is divided into four main segments; glass, metal, plastics, and paperboard (PIRA and REXHAM, 2006), which often compete with one another to supply packaging for products in their main customer industries.
} 
Appendix Two provides a summary of the characteristics of these industries. In the context of $\mathrm{R} \& \mathrm{D}$ and innovation management process industries can be divided into two main groups (see Lager and Blanco, 2010; Lager, 2000), based on supplying either commodity or functional products. For the purposes of this article we adopt the same definitions (Lager and Blanco, 2010: p. 2), to summarise:

- Commodity products- uniform quality, with a low degree of differentiation, which makes them more or less interchangeable. Prices are set on active markets that respond to changes in supply and demand. There are often many suppliers, and goods are easy to transport and store, often in bulk quantities. Customers are often business-tobusiness (B2B), but sometimes business-to-consumer (B2C).

- $\quad$ Functional products- differentiated properties, meaning they are not normally easily interchangeable. Prices are set by suppliers on a cost-plus basis (not market price). Products are produced by a limited number of suppliers and they are not usually delivered in bulk quantities. Customers can be B2B (frequently in long supply chains) or end-users (B2C).

We classify the paperboard packaging industry as a commodity process industry as its products are largely undifferentiated and interchangeable with those of competitors (Fig. 1). This classification can be narrowed down further to "commodity- plus", where specifications can to some extent be modified to meet individual customer needs (Cobbenhagen et al., 1990). Lager and Blanco (2010) have highlighted that each of these types of commodity and functional products can exist both 'upstream' and 'downstream' within the supply chain. The packaging industry's inputs are from raw materials suppliers with their processed product being outputted to (B2B) manufacturers (see Fig. 2). It is classified as a 'downstream' commodity process industry (see Lager and Blanco, 2010).

For product manufacturers within commodity industries 'upgrading' to provide more 
functional value, and to move away from price-based competition, has been a constant challenge (Linn, 1984; Lager, 2000; Lager \& Blanco, 2010). Manufacturers can attempt to 'upgrade' by increasing the level of differentiation in their offering (Linn, 1984; Lager, 2000). Successful 'upgrading' allows manufacturers to increase premiums, moving the buying decision away from purely costs. Over a period of time, functional products will become 'downgraded' to commodities due to imitation by competitors (Linn, 1984; Lager, 2000), hence the cycle (Fig. 1). This study focuses on this critical 'upgrading' process, and attempts to explore and characterise the challenges that exist for R\&D.

Insert Figure 1 about here.

\subsection{Incremental Innovation Orientation}

The existing literature shows that the difficulty facing commodity process industries is one of price: conversations with customers tend to boil down to "How much?" and "At what price?" (Bomsel and Roos, 1990), hence growth and profits are closely linked to purchasing strategies. Recently, Bunduchi and Smart (2010) reviewed the process innovation literature and developed a model of the costs associated with adoption, this included: capital costs, development costs and switching costs. This cost minimal orientation is particularly apparent in many mature industries, such as both the packaging and FMCG industries, where price based competition is high (see Utterback and Abbernathy's innovation lifecycle, 1975). Benner \& Tushman's (2002) study within the paint and photographic industries, suggests that this focus can result in a shift in the balance of innovation, towards efficiency at the expense of long-term adaptation. This in turn creates an emphasis on exploitative activities, crowding out more significant innovations (Benner and Tushman, 2002). Whilst these activities may help firms learn and adapt quickly in the short term, they were seen to inhibit a longer-term focus and lead to inertia (Levinthal, 1991, 1997a; Repenning and Sterman, 2002). This 
creates a pressure on $\mathrm{R} \& \mathrm{D}$ to improve the product and production process to lower costs over time, which can in turn stifle more significant innovation.

The literature on organisational capabilities, offers insight into the different resources and environment necessary for developing incremental and radical innovations. Organisational capabilities are difficult to create and costly to adjust (Nelson and Winter, 1982; Hannan and Freeman, 1984). Incremental innovation reinforces the capabilities of established organisations, while radical innovation forces them to ask a new set of questions, to draw on new technical and commercial skills, and to employ new problem-solving approaches (Burns and Stalker, 1966; Hage, 1980; Ettlie, Bridges, and O'Keefe, 1984; Tushman and Anderson, 1986). The impact of this on the nature of innovation activities is that as the organisation learns and increases its efficiency subsequent innovation is increasingly incremental (Levinthal and March, 1993; Benner and Tushman, 2003). Another constraint on innovation that can arise from this is a shift to meeting existing customer needs (Christensen and Bower, 1996), which impacts on innovation (Trott, 2001; Christensen, 1997). Hence the combination of these factors promote an environment where radical product innovations are overlooked in favour of incremental process developments that deliver benefits for existing customer groups. In the food industry this situation is reinforced by powerful retailers' emphasis on costs.

\subsection{Supply chain position and collaboration}

Research within process industries has shown how important supply chain collaborations are to R\&D and innovation (Cantista and Tylecote, 2008, Sahay, 2003, Soosay et al., 2008). Indeed successful product development often depends on companies' level of understanding and experience of operating in the chain-like structures (Tottie and Lager, 1995). Whilst firms have many potential partners (see Pittaway et al., 2004), supplier-customer relationships have received particular attention within the literature (see Petersen et al., 2003; Chung \& Kim, 
2002; Lambert, 2008; Wynstra et al., 2010). For the supplier, developing a close relationship is critical to gaining the required inputs from customers into the development project (see Leifer et al., 2000). Beyond this, the incorporation of suppliers into product development allows a greater understanding of their needs (Freeman, 1982; Bruce and Rodgus, 1991). This can aid the development of new ideas (Biemans, 1991) and reduce risks (Gemunden et al., 1992). Increasing levels of outsourcing (Fine, 1998; Wynstra et al., 2010) has led to modularisation of products (Baldwin and Clark, 2000) as the product offering becomes distributed across many firms. This has resulted in firms moving away from 'arms length' or transaction orientated purchasing relationships with suppliers, and towards more integrated relation-oriented (see Lambert, 2008; Wynstra et al., 2010), with this communication often handled by 'heavyweights' in the NPD team, who engage in significant external communication and vision setting, leading to more productive projects (Clark and Fujimoto, 1991). Prior research has however highlighted that the potential for the supplier to productively contribute to the customers R\&D is also dependent upon the customer maintaining internal capabilities, in order for the value of new technologies to be recognised internally (see absorptive capacity, Cohen and Levinthal, 1990; Brennan and Turnbull, 1999; Ford and McDowell, 1999; Ritter, 1999).

Insert Figure 2 about here.

Existing research has found that cooperation within the supply chain is more common with 'first tier' suppliers (with which the customer has a direct purchasing and product input relationship), than with second and third-and-below (Fujimoto, 2001; Wynstra et al., 2010). In our study, we would expect high levels of collaborative development to be evident with FMCG and pharmaceuticals firms (see Fig. 2). Indeed, given the significance of packaging to the activities of intermediaries and retailers we may also expect a willingness to cooperate at 
these other (further 'downstream') levels of the supply chain. However, prior studies have highlighted low levels of cooperation within the food \& drink sectors (Stewart-Knox and Mitchell, 2003; Van Dalen et al., 1997). Further, Lindgreen and Wynstra (2005) have suggested that this may be due to the current commodity nature of the (packaging) supplier's offering, which may not fully reflect their technological and innovative capability. Hence, the customer's willingness to collaborate may be dependent upon their view of the supplier's potential contribution to the end product.

\section{Methodology}

The packaging industry is of a commodity-orientated nature (S\&P, 2006), hence for the purposes of our research we select it is an example of a commodity process industry. The industry is very concentrated, having been through a period of consolidation in recent years, and it is now dominated by a small number of large multinationals (Keynote, 2010). Chesapeake represents one of the largest paper and board packaging manufacturers in Europe, and is therefore selected as a 'typical' case organisation (Flick, 2009; Yin, 2009), from the largest of the four packaging sectors ${ }^{2}$. This paper is exploratory in nature, and whilst this case is considered to be typical we recognise that further research is required from our findings.

The research for this paper forms part of a broader collaborative research project (Adler et al., 2003; Shani et al., 2007), which has been running in excess of three years, investigating R\&D management within the packaging industry. Collaborative research is considered a good means to study and model managerial practices and issues (e.g. Shani et al., 2007). This research focuses on presenting the results of a case study within a single firm, based on the researchers collaboration with Chesapeake who sponsored the research. The researchers were invited to the organisation to study a problem that was identified as being relevant and critical to both practitioners and researchers (Starkey and Madan, 2000; Hatchuel, 2001). During this

\footnotetext{
2 There are four main sectors in the packaging industry: paper and board, plastics, glass, and metal. The paper and board sector is the largest of the four (Keynote, 2010).
} 
three-year period over fifty R\&D projects (historical and current) have been examined, covering most of the company's significant clients, and a detailed database of projects has been assembled. It is from this population that we have selected two projects for illustrative purposes. The cases were selected using purposive sampling, with each being 'critical' cases to the organisation, as well as 'illustrative' of the issues the company experienced (Patton, 2002; Flick, 2009). The cases are to be treated as indicative, with the lessons from them suggestive, rather than necessarily being able to be generalised.

A qualitative methodology was used in order to achieve a more complete, holistic, and contextual understanding (Jick, 1979). The study employed an exploratory longitudinal casestudy-based research design (Eisenhardt, 1989; Yin, 2003) over three years. The use of a case study was considered appropriate for this work, as it involves intensive analysis with a view to identifying issues and generating insights (Bryman and Bell, 2003). Focusing on a single case has been found to illustrate interesting phenomena and provide important learning's (Siggelkow, 2007). Furthermore, it is not uncommon in research studies to select a single case for purely practical reasons (Daymon \& Holloway, 2004), especially if it is considered that the case has 'intrinsic value' (Stake, 1995) and provides access to information that would not be available without the ability to focus time and effort solely on one case (Noke, Perrons and Hughes, 2008).

Multiple sources of evidence were used in accordance with principles of 'triangulation' (Yin, 1994; Flick, 1998; Eisenhart, 1989) in order to minimise subjectivity, which included interviews and observations over the three-year period, attendance at R\&D meetings, and meetings with key suppliers and customers. Data was also gathered from internal presentations and documentation, as well as email communications. With respect to the interview study, the paper draws upon information gathered from key members of the organisation, as well as interviews with other key supply chain partners relevant to the R\&D 
projects and process (summarised in Table 3). This process was designed to capture how different players viewed, interacted and worked with each of the projects studied. The case study followed the procedures set out by Yin (2009). Set questions were developed for the interviews, although departures from this structure were permitted in the interest of exploring new and potentially fruitful points. Finally, the findings were validated by feedback to the interviewees involved in the research (Flick, 2009).

\section{Findings}

\subsection{Packaging and the Packaging Industry}

Chesapeake is a leading supplier in the $£ 9.49$ billion UK packaging sector (Keynote, 2010). The primary customers of this sector are the FMCG and pharmaceuticals industries. These firms have outsourced many of their non-core manufacturing activities, which raises the importance of supplier relations with the packaging manufacturers. Indeed, for these industries the packaging forms a critical part of the product offering, particularly within the current competitive climate. According to PIRA International (the packaging industry's research association), packaging is vital in this process of differentiation; "with the number of brands available on the shelves increasing constantly... Distinguishing products from one another becomes the biggest task for the consumer" (2011). This is reflected in some producers pursuing packaging change to compete in a saturated market, with changes being made with respect to, size and shape (e.g. Coca-Cola fridge packs), printing of labels (Tetra Pak cartons requiring different printing processes to previous forms of packaging), and materials (PET bottles). Furthermore there is considerable pressure on firms to curb their packaging and reduce their environmental impact (Mintel, 2009; GMID, 2011). Process developments have helped firms to achieve these aims, such as reducing the amount of material required to produce a pack. 
The packaging industry itself is characterised by fierce competition for demanding customers, which is compounded by an increasing level of competition from suppliers in emerging countries. This has led to reduced margins on the products sold by companies in the sector. Packaging has also received negative publicity from the environmental lobby. In the case of the paperboard sector the majority of products it produces are of a commodity nature. Figure 3 captures the significant innovations within this sector over the past 100 years. The sector has faced increasing competition from plastics, despite the environmental advantages of paperboard packaging (Keynote, 2010). Furthermore, customers often view packaging negatively and regard it as a necessary evil or an unnecessary cost, despite its importance and potential contribution to the end product. This is exemplified by Lockamy (1995, p. 52) who claims that many organisations see packaging as an "unavoidable non-value-added cost containing little of no strategic value". This myopic view reinforces the emphasis on cost reductions leaving little room for creativity, which has arguably inhibited the development of both product and process innovations.

Insert Figure 3 about here.

\subsection{Chesapeake}

Chesapeake develops and manufactures a wide variety of packaging, particularly for specialty and branded goods. In 2009 Chesapeake separated from a larger American corporation, with a venture capital firm acquiring the European operations. These changes had little impact on its $\mathrm{R} \& \mathrm{D}$, budget, or strategy.

Chesapeake's R\&D team consists of eight key managers, engineers, designers, and scientists, and ten operational level staff. $R \& D$ projects were primarily driven from: sales teams, marketing information (largely from the sales force), and internal technology led projects. 
This was confirmed by $\mathrm{P} 2$ "we undertake two types of $R \& D$, pure $R \& D$ which is our version of blue sky, and sales led $R \& D ”$. The majority of activities were market led, particularly due to the relatively low expenditure on $\mathrm{R} \& \mathrm{D}$, at "between $2-3 \%$ of sales" [P2], which was partly associated with the low margins of their largely commodity products.

The following reports on two packaging R\&D projects, an overview is provided in Table 1 .

Insert Table 1 about here.

\subsection{Project A- Formable Board}

Project A, internally referred to as "formable board" [P5], is a joint development project between Chesapeake and a Swedish paper and board materials supplier. The board supplier approached Chesapeake with a newly developed and patented (solid bleach sulphate) board material with the unique quality of being able to 'stretch' by between $5-10 \%$, meaning that it could be formed into shapes or embossed effects. This differentiated it from other board packaging which could only be cut, folded, creased, or curved. Hence the technology was considered to be "one of the most significant packaging innovations in the history of the paperboard packaging industry" [P2]. This could provide Chesapeake with new opportunities to compete with more flexible materials (particularly plastics), and enable board to be utilised in new product applications.

While substantial material development had already been undertaken by the board supplier, it lacked the ability to implement the board into a production line, develop an appropriate manufacturing process for different applications, and make it commercially viable. Furthermore, it had little direct contact with FMCG firms [P9], who ultimately purchased 
manufactured packaging. For Chesapeake this was a project with large upfront costs. As a result, the Head of R\&D [P2] initially wanted to "establish an exclusive contract" of sole supply, to ensure payback from the investments. The board supplier initially rejected the proposal forcing Chesapeake to take on this risk; although in early 2011 an agreement was made based on the development work undertaken, mitigating the risk of these investments.

Chesapeake approached a number of existing and potential customers (see target markets, Table $1^{3}$ ) but struggled to verify the best current, and possible future, target markets and applications for the technology. Chesapeake's main point of contact was through its sales force who spoke to buyers within customer firms. These discussions were not productive. The buyers were focused on reducing the costs of existing products that Chesapeake supplied and were not interested in new products. In some cases Chesapeake was able to communicate with packaging technologists but, whilst they recognised potential benefits in the technology, these technologists had little role in decision-making. The Head of R\&D [P2] highlighted the key problem this created:

"we cannot miss out on this opportunity, but it is hard to know how much potential it has... what barriers we may have to overcome to make it successful.... [and] where it has the greatest potential... across various categories” [hence] “......we don't know where to target this technology, as we have no insights into the priorities or future strategies of FMCG firms, and therefore we don't know what the best applications for this technology are.... [and] ... where to target our investment” [P2].

Early in the project different technical challenges were identified. Tests found that, when making large formed shapes, the 'male' and 'female' plates used to form materials on most existing equipment would "bend before enough pressure had been applied to form the

\footnotetext{
${ }^{3}$ The focus on OTC, as opposed to prescription, drugs was due to different legislation that made it slightly easier for packaging changes to be made.
} 
board" [P2]. On the other hand smaller shapes, such as blister packs for pills, could be made using existing tooling, thereby lowering switching costs. Whilst this was seen as a potential advantage, Chesapeake was unable to establish the potential for the technology in this sector. Initially, the team wanted to identify a lead user or target sector for the adoption of the technology. This would allow them to target their investment on a particular application "in order to get the technology established and get returns on the investments" [P8] made. However, the above issues precluded the team from adopting this strategy.

Later in development, the team was inhibited in developing prototypes to illustrate the potential applications of the technology. Without customer insights it was possible to only make a few general prototypes to show to prospective client firms (in order to keep costs low), which was "not the optimal way of demonstrating the product" [P3] for the sales staff. At this stage problems were also experienced marketing the new innovation to its clients, again resulting from the buyer interface:

"they are unkeen (sic) to make changes, as it will put up the costs of the materials which can lower their bonuses.... even small cost increases are avoided" [P5].

"The buyer interface is a big issue.... It is difficult to get past the buyer to speak to other staff for whom new packaging could potentially add value...... In some cases if we try to communicate with others within the firm we risk loosing the contract, as the buyers get bonuses for buying packaging cheaply and therefore they do not want other staff to be pushing for more expensive packaging” [P3].

As a result the team was hampered in "contacting other members of the NPD teams in order to establish their interests...." [P7]. The team was frustrated as it became difficult to build a business case for the technology, due to their level of insight, meaning that it was hard to establish when its investments would be recouped and from which sectors. 


\subsection{Project B-Milk Pouch}

Project B focuses on the development of a new type of packaging for milk and milk alternatives. Plastic bags, as a format for packaging milk, had been used since the 1960's, but they had proven unpopular. Recently some supermarkets were starting to use them again as they minimised packaging, with obvious environmental and cost benefits. The project team also linked this renewed interest in the format with an overall increase in the use of 'pouches' (including retort pouches) within the FMCG sector. Indeed the key informants considered this to be one of the most significant recent industry trends.

The development team's early analysis highlighted that a milk bag's lack of ability to 'stand up', meant that it was necessary for consumers to put them into a jug for opening, storage and use. For retailers this also affected the display of the product on their shelves, and the format was seen to have a look of "poor quality" [P2]. The team focused on developing an alternative that would cut costs and material usage, whilst retaining some rigidity in order to be freestanding. They began developing a milk bag with a "built in 'spine' that will support the bag and provide rigidity" [P2]. This would keep weight and waste lower than a plastic bottle or carton but would be more convenient than the existing bags.

Chesapeake began to explore possible structures and materials, whilst attempting to establish the likely demand, potential customers, and specific customer development requirements. Again buyers formed the primary interface, hindering the team from gaining deeper insights into the potential for the product. For example: 
"the buyers have no interest in the new technology as their focus is on cost reduction of existing formats... [but it was hard to] communicate the technology to other members of staff in the client firm" [P2].

Meetings were also held with packaging technologists, but despite positive feedback, they lacked the ability to actually implement the packaging into products, as decisions were down to Category, Product, or Brand managers. A meeting with a key FMCG client illustrated some of these issues. P11 took interest in the product, however he noted 'I don't have any say in the decisions", as this was down to "Category Managers to specify the packaging to be used on the product", similarly P10 stated "I don't have the decision making power". Where the team were able to contact key decision makers they expressed "little interest in meeting with packaging manufacturers" [P7 \& $\mathrm{P} 2]$.

This point of contact, and the nature of communications, hindered the project. The current format of packaging used by firms was typically cartons or PET bottles. Any process change was viewed only in terms of additional costs rather than an opportunity to add value and increase margins. For example, Chesapeake was unable to engage in discussions on the specifications for the product. For example, the spine could be made from a number of materials, or with the rigidity coming from the polymeric formulation. The team eventually chose to focus on a new polymeric formulation technology that would change properties depending on the temperature in which it was stored. Meaning that the bag would be able to provide rigidity when cooled, and hence whilst it stored the milk. But, it would lose rigidity in ambient temperatures, allowing it to be compacted during the remainder of its lifecycle and through disposal ${ }^{4}$. The team's decision was based largely on the company's capabilities, as customer and market knowledge was not forthcoming (such as demand, price, rigidity, and environmental appeal). Finally, exploring collaboration opportunities to develop factory trials

\footnotetext{
4 The use of a polymeric formulation was the chosen core focus for the R\&D project, with the company sponsoring a University research project to develop the technology.
} 
were hindered as dairies were reluctant to consider any proposal that might affect their fragile margins.

\section{Analysis and research agenda}

In this section we present the analysis of the cases, as well as supporting evidence from the three-year study, and develop six propositions for further research. Our analysis highlights five barriers for R\&D; these hinder packaging manufacturers' ability to 'upgrade' to the supply of functional products (summarised in Table 2).

Insert Table 2 about here.

(i) Costs. The sunk capital equipment costs in the production line of Chesapeake's clients acted as a barrier to change, due to the investments required. As a result the focus of innovation can be characterised as, short-term (primarily process efficiency and unit costs), incremental, and changes were driven by design and the market. The importance of process change costs and the focus on efficiency is not a significant revelation in itself (e.g. Utterback and Abbernathy, 1975; Benner \& Tushman, 2002). However, the findings provide new insights into the high level of $\mathrm{R} \& \mathrm{D}$ time spent on "minimising changes to the production line associated with new technologies" [P2], as illustrated Project A with regards to OTC pharmaceuticals. Potential unit cost increases also acted as a barrier, which was highlighted by P15:

"we are a market leader [in the process used for their current packaging format] having driven costs to a minimum over many years, this is a key advantage, but it 
also constrains us. The further we drive down costs, the more we become tied to our format as the effect on our margin would be significant...."

The above analysis leads us to develop the following proposition:

Proposition 1: A customer's focus on efficiency and exploitative innovation, and the avoidance of production line change acts as a barrier to a packaging manufacturer's $\mathrm{R} \& \mathrm{D}$, hindering its ability to 'upgrade'.

(ii) Emergence of powerful buyers. The packaging formats used by most of Chesapeake's clients were largely well established, undifferentiated and available from many suppliers. This meant that in NPD client firms often specified a standard type of packaging and then entrusted buyers to purchase that packaging (commodity) at the lowest possible cost. This lead to a heavy focus on cost, which acted as almost the sole criteria in supplier selection, as Bomsel and Roos (1990) suggest.

Our findings build on existing literature on supplier relationships (Lincoln et al., 1998; Petersen et al., 2003; Chung \& Kim, 2002; Lambert, 2008), providing novel insights into the impact of this cost transaction based purchasing relationship (see Wynstra et al., 2010). The buyer interface had a significant influence in this commodity industry, creating an obstacle to gaining insights and accessing key decision makers. Hence the company was unable to answer critical questions in the development project, such as identifying the best target markets, likely demand, and the specifications required by the customer (see Leifer et al., 2000). Chesapeake's R\&D was effectively "tunnel visioned [as client contact is commonly confined to] responding to a brief.... therefore there is no dynamic view or understanding" [P2]. In addition, buyers received bonuses for purchasing packaging cheaply, which added to this problem, as it meant that they did not want packaging firms speaking to other decision makers. Thus we propose: 
Proposition 2: A cost transaction relationship between a packaging supplier and its customer acts as a barrier to $\mathrm{R} \& \mathrm{D}$, hindering the supplier's ability to upgrade due to of a lack of meaningful customer input into the innovation process.

(iii) Insufficient Packaging Champions. The commodity status of the packaging used the end consumer product meant that FMCG and pharmaceutical companies commonly allocated the responsibility for packaging to buyers. This created two key problems. Firstly, it resulted in a "lack of internal staff focused on the development" [P2] of packaging and innovation, and a lack of technical expertise in client firms. The existing literature refers to 'heavyweights' in NPD (Clark and Fujimoto, 1991). This case highlights the critical impact of the lack of staff acting as packaging 'heavyweights', or where packaging staff did exist their lack of influence on decision-making. One interviewee illustrated how this limits the potential contribution packaging can make to the product: "our packaging is just a paper bag", the team therefore "just focus[ed] on getting the cheapest" [P17]. Furthermore, there was no one to act as an interface and facilitate networking. Consequently it was hard to establish strategic and long-term collaborative relationships. Packaging was not considered as an ongoing business activity. Its consideration is ad-hoc, particularly as there is no one internally 'championing' packaging development and facilitating collaboration. Hence:

Proposition 3: A lack of staff with technological packaging capability within the customers of packaging firms will result in packaging development being overlooked. This in turn acts as a barrier to R\&D impeding the packaging firm's ability to 'upgrade'.

Proposition 4: The commodity status of a packaging firm's current offering will hinder the ability of its R\&D to develop products to 'upgrade', due to customers perceiving the supplier to lack the ability to add value to their product. 
(iv) Language and Definition of 'Packaging Development'. The lack of packaging champions and experts had another impact. The interviews revealed that the key decision makers and NPD team members attached different meanings to the development of packaging. For example, marketing staff talked about packaging development being integral to NPD, but were actually discussing label changes [P16,P21,P22], similarly design staff considered packaging development to be key, but were actually only considering basic aesthetic and graphic changes [P12,P13]. As a result the potential for technological development adding value was being inadvertently overlooked. This created a 'language' barrier between the firms, affecting collaboration. These findings are closely related to the issue of absorptive capacity (Cohen and Levinthal, 1990), however the existing literature does not account for this language issue. Thus:

Proposition 5: The lack of internal 'heavyweights', within the customers of the packaging industry, will result in a myopic view of the meaning of "packaging development'. This in turn will impede the packaging suppliers ability to 'upgrade', due to decreased interactions between the firms.

(v) Supply Chain Position. The final barrier is linked to packaging manufacturers' position in the supply chain. Whilst the industry is classified as being downstream (Lager and Blanco, 2010), a key issue was highlighted with respect to it being far (upstream) from end consumers in the overall supply chain. This acted as a "barrier to gaining insight" [P2], meaning they were reliant on their 'downstream' partners. However, we found low levels of collaboration on projects amongst these 'downstream' supply chain members, which limited consumer insight. Chesapeake was unable to gain access to data on or from these members of the supply chain. These difficulties were summarised by P2:

"they wont allow us access to any data... most of the top blue chip companies in Europe are customers of Chesapeake. These companies rely on packaging suppliers 
for the next generation of products ... But we aren't seeing the right people, as all we can get access to is buyers...".

The impact of the low level of collaboration with these members of the supply chain was particularly acute in the case of own-brand products, and exacerbated by the fact that the retailers did not produce the products themselves, limiting communications further. This, combined with the product suppliers focus on costs, hindered the adoption of developments, which had to be "pushed on to both the retailers and manufacturers, as the manufacturer will be happy with what they have got and want to keep costs low... " [P2]. Indeed in some cases suppliers would only consider changing if the retailer threatened to switch to a new supplier, however where suppliers were larger this was difficult due to their "relative power" [P2]. This leads us to our final proposition:

Proposition 6: A lack of willingness among downstream supply chain members $\left(2^{\text {nd }}\right.$, $3^{\text {rd }}$, tier or below) to cooperate, will act as a barrier to R\&D developing products to 'upgrade'.

The propositions presented in the preceding discussions lead the way forward for future research. In presenting these propositions we note that some firms will produce both commodity and functional products, a potential avenue for future research could be to investigate whether differences exist depending on how many products a firm sells are commodity/functional. Further research is needed to verify these for the industry as a whole, and compare these to other industries, both upstream and downstream.

\section{Conclusions}

This paper has characterised the challenges to R\&D management when attempting to 'upgrade' within the commodity-orientated packaging industry. We contribute to this stream of research on the upgrade downgrade cycle (Lager, 2000), by identifying five barriers facing 
R\&D within this industry. Three of these barriers deserve particular attention. Firstly we build on the existing literature on absorptive capacity (Cohen and Levinthal, 1990; Brennan and Turnbull, 1999; Ford and McDowell, 1999; Ritter, 1999), by providing new understanding in the case of the packaging industry. The combination of the outsourcing of packaging by FMCG and pharmaceutical firms has led to the emergence of powerful buyers who are preoccupied with cost reductions and overlook new packaging innovations. The unintended consequence of this is a reduction in absorptive capacity for the FMCG and pharmaceutical firms (Cohen and Levinthal, 1990; Brennan and Turnbull, 1999; Ford and McDowell, 1999; Ritter, 1999). The second barrier is the language barrier. Within the FMCG and pharmaceutical sectors packaging development seems to be viewed superficially and is taken to mean labelling or aesthetic design changes. The result is that the potential for technological change and more fundamental packaging changes are overlooked. The third barrier is the lack of internal packaging champions within FMCG firms. With respect to this barrier we have highlighted a perceptual problem within the FMCG NPD team, which results from the commoditisation of the suppliers inputs (Lindgreen and Wynstra, 2005). The impact of this commoditisation is that packaging firms were viewed pejoratively within FMCG and pharmaceuticals firms, as suppliers of 'cardboard boxes', which led to its innovation potential and R\&D activities being overlooked.

The R\&D and innovation literature contains relatively few studies on process industries. Case studies, such as the one presented in our paper, usefully add to the current stock of knowledge. Using the case study research method we have been able to gain rich insights into a number of challenges to R\&D management within this commodity orientated industry. A key contribution is the development of six propositions that form the basis of an agenda for future research into the upgrade aspect of the cycle. Of course the findings of a case study have limitations in terms of generalisation, and hence further research is required in order to 
test these propositions more widely within the packaging industry, and to compare these barriers to those in other commodity orientated process industries.

R\&D Managers within process industries will benefit from the insights provided by the cases presented in this research paper, which provide them with better understanding of these barriers when applied to, for example, project selection and resource allocation decisionmaking. R\&D managers may be able to exert influence on some aspects of the identified barriers, such as lowering the unit and capital equipment costs associated with the adoption of a new innovation. However, other aspects are less easy to influence, such as the emphasis on exploitative and incremental innovation that results from this cost focus. The emergence of powerful buyers, supply chain position and language problems, all seem to be largely beyond the direct control of R\&D managers. Although the further research that we have suggested in this paper may prove useful in developing understanding and uncovering strategies to tackle these barriers.

\section{References}

Adler, N., Shani, A.B., Styhre, A. (2003) Collaborative research in organizations:

Foundations for learning, change and theoretical development, Sage, London.

Arora, A \& Gambardella, A. (1990) "Complimentarity and external linkages: The strategies of the large firms in biotechnology". The Journal of Industrial Economics, 38, 4, pp. 361-379. Ashayeri, J. Teelen, A. (1996) "A production and maintenance planning model for the process industry", International Journal of Production Research, 34, 12, pp. 3311-3326.

Auster, E. (1992) “The relationship of industry evolution to patterns of technological linkages, joint ventures and direct investment between U.S and Japan”, Management Science, 38,6, pp. 778-792.

Baldwin, C.Y. and Clark, K.B. (1997) "Managing an age of modularity". Harvard Business Review, 75, 5, pp. 84-93. 
Benner, M. \& Tushman, M. (2002) "Process Management and Technological Innovation: A Longitudinal Study of the Photography and Paint Industries”. Administrative Science Quarterly, 47, 4.

Biemans, W. (1991) "User and third-party involvement in developing medical equipment innovations", Technovation, 11,3, pp. 163-182.

Bomsel, O. \& Roos, P. (1990) "From commodities to evolutionary materials". Resources policy, June, pp. 104-114.

Brennan, R. and Turnbull, P.W. (1999), "Adaptive behavior in buyer-supplier relationships", Industrial Marketing Management, 28, pp. 481-95.

Bruce, M. \& Rodgus, G. (1991) "Innovation strategies in the enzyme industry”, $R \& D$ Management, 21,4, pp. 319-330.

Bryman, D. and Bell, E. (2003) Business Research Methods, Oxford University Press.

Burns, T. \& Stalker, G.M. (1966) The Management of Innovation, 2nd edition, London, Tavistock Publications.

Bunduchi, R. \& Smart, A. (2010). 'Process innovation costs in supply networks: a synthesis'. International Journal of Management Reviews, vol 12, no. 4, pp. 365 - 383.

Burt, R.S. (1992). Structural Holes: The Social Structure of Competition. Cambridge MA: Harvard University Press.

Cantista, I. \& Tylecote, A. (2008) "Industrial innovation, corporate governance and suppliercustomer relationships", Journal of Manufacturing Technology, 19, 576-590.

Chesbrough, Henry (2006) Open Innovation: A New Paradigm for Understanding Industrial Innovation," in Henry Chesbrough, Wim Vanhaverbeke, and Joel West, eds., Open Innovation: Researching a New Paradigm. Oxford: Oxford University Press, 1-12.

Christensen, C.M. (1997), The Innovator's Dilemma: When New Technologies Cause Great Firms to Fail, HBS Press, Cambridge, MA.

Christensen, C.M. and J.L. Bower. (1996) "Customer Power, Strategic Investment, and the Failure of Leading Firms", Strategic Management Journal, 17, pp. 197-218.

Chung, S., Kim, G.M. (2002) "Performance effects of partnership between manufacturers and suppliers for new product development: the supplier's standpoint”, Research Policy, 1404, pp. $1-17$.

Clark, K. \& Fujimoto, T. (1991) Product development performance, Boston MA: Harvard Business School Press. 
Cobbenhagen, J., Den Hertog, F. \& Philips, G. (1990) Management of innovation in the processing industry: a theoretical framework, London, Printer Publishers.

Cohen, W. and Levinthal, D. (1990) "Absorptive Capacity: A new perspective on learning and innovation". Administrative Science Quarterly, 35, pp. 128-152.

Daymon, C. \& Holloway, I. (2002) Qualitative research methods in Public Relations and Marketing Communications. London: Routledge

Eisenhardt, K. (1989). "Building theories from case study research", Academy of Management Review, 14, 4, 532-550.

Ettlie, J.E., Bridges, W.P. and O'Keefe, R.D. (1984) “Organisation strategy and structural differences for radical versus incremental innovation", Management Science, June, 30,6, Fine, C.H. (1998) Clockspeed: Winning Industry Control in the Age of Temporary Advantage, Reading MA, Perseus Books.

Flick, U. (1998). An Introduction to Qualitative Research. SAGE Publications.

Ford, D., \& McDowell, R. (1999). "Managing business relation- ships by analyzing the effects and value of different actions”, Industrial Marketing Management, 28, pp. 429-442. Freeman, J. (1982) "Organizational lifecycles and natural selection processes". pp 1-32 in Staw, B. \& Cummings, L. (Eds.). (1982) Research in Organizational Behaviour, Greenwich CT: JAI Press.

Gemunden, H., Heydebreck, P. \& Herden, R. (1992) “Technological interweavement: a means of achieving innovation success", R\&D Management, 22, 4, pp. 359-376.

GMID. (2011). Global New Packaging Developments 2009-2010. Retrieved June 14, 2011, from $\underline{\text { http://www.portal.euromonitor.com/Portal/Pages/Search/GeographyTreePage.aspx }}$

Groover, M.P. (1987) Automation, production systems and Computer Integrated Manufacturing, Prentice-Hall, Inc., Englewood Cliffs, NJ

Gulati, R. \& Singh, H. (1998) "The Architecture of Cooperation: Managing Coordination Costs and Appropriation Concerns in Strategic Alliances", Administrative Science Quarterly, 43.

Hage, J. (1980) Theories of Organizations, John Wiley \& Sons, New York, 1980.

Hagerdoorn, J. (2002) "Inter-firm R\&D partnerships: an overview of major trends and patterns since", Research Policy, 31, pp. 477-492.

Hannan, M. and Freeman, J. (1984) "Structural inertia and organizational change", American Sociological Review, 49, pp. 149-164. 
Hatchuel, A. (2001), “The two pillars of new management research", British Journal of Management, 12, 4, p. 41.

Herzog, P. and Niedergassel, B. (2007) "Facilitating Open Innovation: Idea Brokers in the Chemical Industry", PharmaChem, March 2007, pp. 10-12.

Hoecht, A. \& Trott, P. (2006) "Outsourcing, information leakage and the risk of losing technology based competencies", European Business Review, 18,5, pp. 395-412.

Howells, J. (2008) "New directions in R\&D: current and prospective challenges". $R \& D$ Management, 38, pp. 241-252.

Hayes, R.H., Wheelwright, S.C. (1979) "Link Manufacturing Process and Product Life Cycles", Harvard Business review, Jan-Feb.

Jick, T. (1979) “Mixing qualitative and quantitative methods: triangulation in action", Administrative Science Quarterly, 24,4, pp. 602-611.

Johnson, M. W., Christensen, C. M. \& Kagermann, H. (2008) "Reinventing your Business Model", Harvard Business Review, December, pp. 51-59.

Keynote (2010) Market Report: Packaging (Paper and Board), Fifteenth Edition, March 2010

Koene (1988) logistick in de procesindustrie, Tijdschrift voor Inkoop en Logistiek, jrg. 4, No. 12 (Dutch)

Krackhardt, D. (1992) "The strength of strong ties: The importance of philos in organizations". P216-239 in Networks and Organisations: Structure, Form and Action, edited by Nohria, N \& Eccles, R. (1992) Boston MA: Harvard Business School Press.

Lager, T. (2000) “A new conceptual model for the development of process technology in Process Industry”, International Journal of Innovation Management, Vol. 4, pp. 319-346.

Lager, T. \& Blanco, S. (2010) “The Commodity Battle: a product-market perspective on innovation resource allocation in the Process Industries", International Journal of Technology Intelligence and Planning, 6,2, pp. 128-150

Lambert, D.M. Supply Chain Management: Processes, Partnerships, Performance, Third Edition, Sarasota, FL: Supply Chain Management Institute, 2008, pp. 1-23.

Lambert, D.M., \& Cooper, M.C. (2000) “Issues in Supply Chain Management”, Industrial Marketing Management, 29, pp. 65-83. 
Leifer, R., McDermott, C., Colarelli, G. Peters, L.S., and Price, M. (2000) Radical Innovation: How Mature Companies Can Outsmart Upstrarts, Harvard Business School Press.

Leonard-Barton, D. (1992) “The factory as a learning laboratory”, Sloan Management Review, 34,1, pp. 23-38.

Levinthal, D.(1991). "Organizational adaptation and environmental selection: Interrelated processes of change", Organizational Science, 2, pp.140-145.

Levinthal, D.(1997). “Adaptation on rugged landscapes". Management Science, 43, 7, pp. 934-950.

Levinthal, D.A. and March, J.G. (1993) “The Myopia of Learning”, Strategic Management Journal, 14, Winder 1993, pp. 95-112.

Lincoln, M, Harland, C. and R. Brennan (1998) "Developing supplier relationships”, British Journal of Management, 8, pp. 57-71

Lindgreen, A., Wynstra, F. (2005), "Value in business markets: What do we know? Where are we going?" Industrial Marketing Management, 34, 7, pp 732-748

Linn, R. A. (1984) "Product Development in the Chemical Industry: A Description of a Maturing Business". Journal of Product Innovation Management, 2, pp. 116-128.

Lockamy, A. (1995) "A Conceptual Framework For Assessing Strategic Packaging Decisions", International Journal of Logistics Management, 6, 1, pp.51 - 60.

Mintel (2009). Consumer Food Packaging - UK. Retrieved June 14, 2011, from http://academic.mintel.com/sinatra/oxygen_academic/search_results/show\&/display/id=4797 95/display/id=503608\#hit1

Nag, R., Corley, K. G., \& Gioia, D. A. (2007) “The intersection of organizational identity, knowledge, and practice: Attempting strategic change via knowledge grafting". Academy of Management Journal, 50, pp. 821-847.

Nelson, R.R and Winter, S.G.(1982). An Evolutionary Theory of Economic Change. Harvard University Press.

Noke, H., Perrons, R. \& Hughes, M. (2008) "Strategic dalliances as an enabler for discontinuous innovation in slow clockspeed industries: evidence from the oil and gas industry". R\&D Management, 38, 2, pp. 129-139.

Nieuwenhuis, L.F.M. (2002) "Innovation and learning in agriculture”. Journal of European Industrial Training, 26, 6,7, 283. 
Orsenigo, L., Pammolli, F. and Riccaboni, M. (2001) “Technological Change and Network Dynamics: Lessons from the Pharmaceutical Industry”, Research Policy, 30, 485-508

Patton, M.Q. (2002) Qualitative evaluation and research methods, $3^{\text {rd }}$ ed, London, Sage.

Petersen, K.J., Handfield, R.B., \& Ragatz, G.L. (2003) "Supplier integration into new product development: coordinating product, process and supply chain design". Journal of Operations Management, 23, pp. 371-388.

Simms, C. \& Trott, P. (2010) "Packaging development. A conceptual framework for identifying new product opportunities", Marketing Theory, 10, 4, pp. 397-415.

Pittaway, L. Robertson, M., Munir, K, Denyer, D and Neely, A. (2004) "Networking and innovation: a systematic review of the evidence", International Journal of Management Reviews, 5/6, 3\&4.

Porter, M.E. (1985) Competitive Advantage, Ch. 1, pp 11-15. The Free Press. New York. Powell, W., Koput, K. \& Smith-Doerr, L. (1996) "Interorganizational collaboration and the locus of innovation: Networks of learning in biotechnology". Administrative Science Quarterly, 4, pp. 116-145.

Reichstein T, Salter A, (2006) "Investigating the sources of process innovation among UK manufacturing firms", IND CORP CHANGE,15, pp. 653-682

Repenning, N. \& Sterman, J. (2002) "Capability traps and self-confirming attribution errors in the dynamics of process improvement". Administrative Science Quarterly, 47, 265-295.

PIRA International (2011) Market Report, Available from: http://www.pirainternational.com/Modules/eComm/Listing.aspx?contentID=8686\&Typeid=1

Pittaway, L., Robertson, M., Munir, K., Denyer, D., Neely, A. (2004) "Networking and innovation: a systematic review of the evidence", International Journal of Management Reviews, 5, 3-4, Sept 2004.

Ritter, T. (1999), "The Networking Company: Antecedents for Coping With Relationships and Networks Effectively". Industrial Marketing Management, 28, 5, pp. 467-479.

Rundh, B. (2005) "The multi-faceted dimension of packaging: Marketing logistic or marketing tool?" British Food Journal, 107, 9, pp. 670-684.

S\&P (2006) Standard and Poor's guide, 2006 Edition, McGraw Hill Professional.

Sahay, B. (2003) "Supply chain collaboration: the key to value creation", Work Study, 52, pp. 76-83.

Shani, A.B., Mohrman, S.A., Pasmore, W.A., Stymne, B., and Adler, N. (2007) Handbook of 
Collaborative Management Research, Sage, London.

Siggelkow, N. (2007). "Persuasion with Case Studies." Academy of Management Journal, 50, pp. 20-24.

Silayoi, P. and Speece, M. (2007) "The importance of packaging attributes: a conjoint analysis approach", European Journal of Marketing, 41, 11/12, pp.1495 - 1517.

Soosay, C. A., Hyland, P. W. \& Ferrer, M. (2008) Supply chain collaboration: capabilities for continuous innovation. Supply Chain Management: An International Journal, 13, 2, pp. 160169.

Stake, R. (1995) The art of case research. Thousand Oaks, CA: Sage Publications.

Starkey, K.; Madan, P.(2001) "Bridging the Relevance Gap: Aligning Stakeholders in the Future of Management Research", British Journal of Management, Vol. Special issue 1, pp.326.

Standard \& Poor (2006) The Standard and Poor's 500 Guide, McGraw-Hill Professional 2006.

Stewart-Knox, B. \& Mitchell, P. (2003) "What separates the winners from the loosers in new product development?" Trends in Food Science and Technology, 14, 58-64.

Streb, J. (2003) "Shaping the national system of interindustry knowledge exchange: vertical integration, licensing and repeated knowledge transfer in the German plastics industry", Research Policy, 32, pp. 1125-1140.

Tapon, F. \& Thong, M. (1999) "Internal Versus External R\&D: A Study of R\&D Choicewith Sample Selection”. R\&D Management, 29, 3, 219-231.

Tottie, M. \& Lager, T. (1995) "QFD-Linking the Customer to the Product Development Process as a Part of the TQM Concept”. R\&D Management, 25, 3, 257-267.

Trott, P. (2001) "The role of market research in the development of discontinuous new products", European Journal of Management, 4, 3, pp. 117-125.

M. L. Tushman and P. Anderson (1986) "Technological discontinuties and organizational environments", Administrative Science Quarterly, 31, pp. 439-65.

Utterback, J. \& Abbernathy, W. (1975) “A dynamic model of process and product innovation", Omega, 3, 6, 639-656.

Van Dalen, J. H., Hilberts, B., \& Enzing, C. M. (1997) Kennisinstel- lingen en MKB spreken elkaars taal niet. Voedingsmiddelentech- nologie, 12, 53-55. 
Wynstra, F., Corswant, F., and Wetsels, M. (2010) "In Chains? An empirical study of antecedents of supplier product development activity in the automotive industry", Journal of Product Innovation Management, 27, pp. 625-639.

Yin, R. (1994) Case Study Research; Design and Methods, Sage, Thousand Oaks, CA.

Yin, R. (2003) Application of Case Study Research, $2^{\text {nd }}$ Edition, SAGE Publications.

Yin, R. (2009) Case Study Research: Design and Methods, $4^{\text {th }}$ Ed, Applied Social Research Methods Series, 5, Sage, London. 
Figure 1: The 'upgrade-downgrade cycle (Lager, 2000)

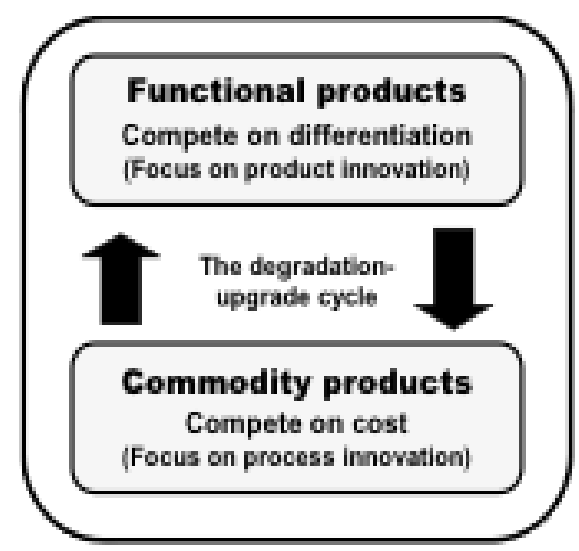


Figure 2: Simplified structure summarising product and packaging supply chain for packaged FMCG goods

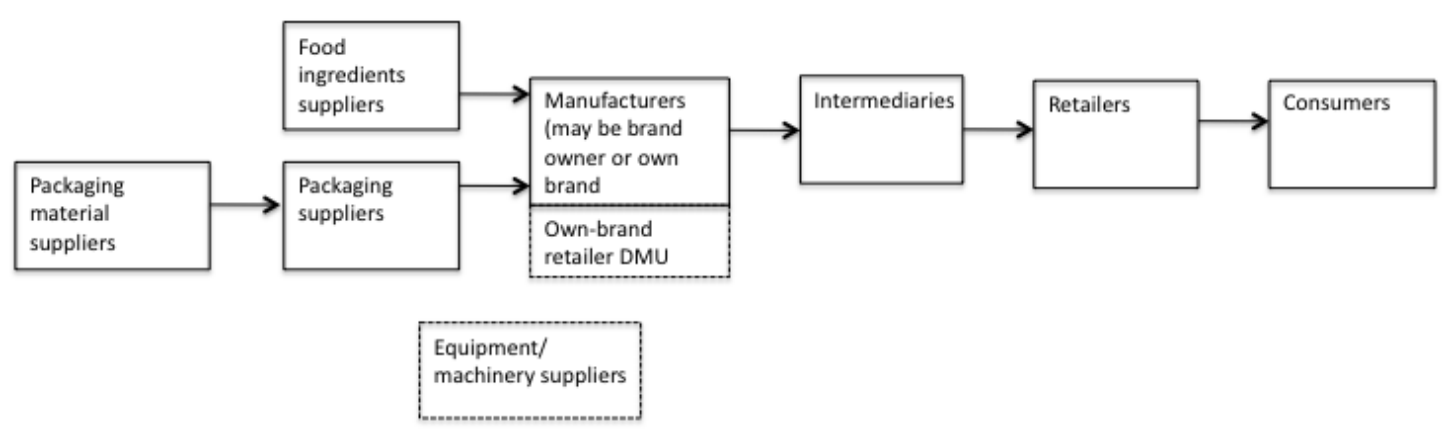


Figure 3: Significant paper and board packaging innovations over the past one hundred and ten years

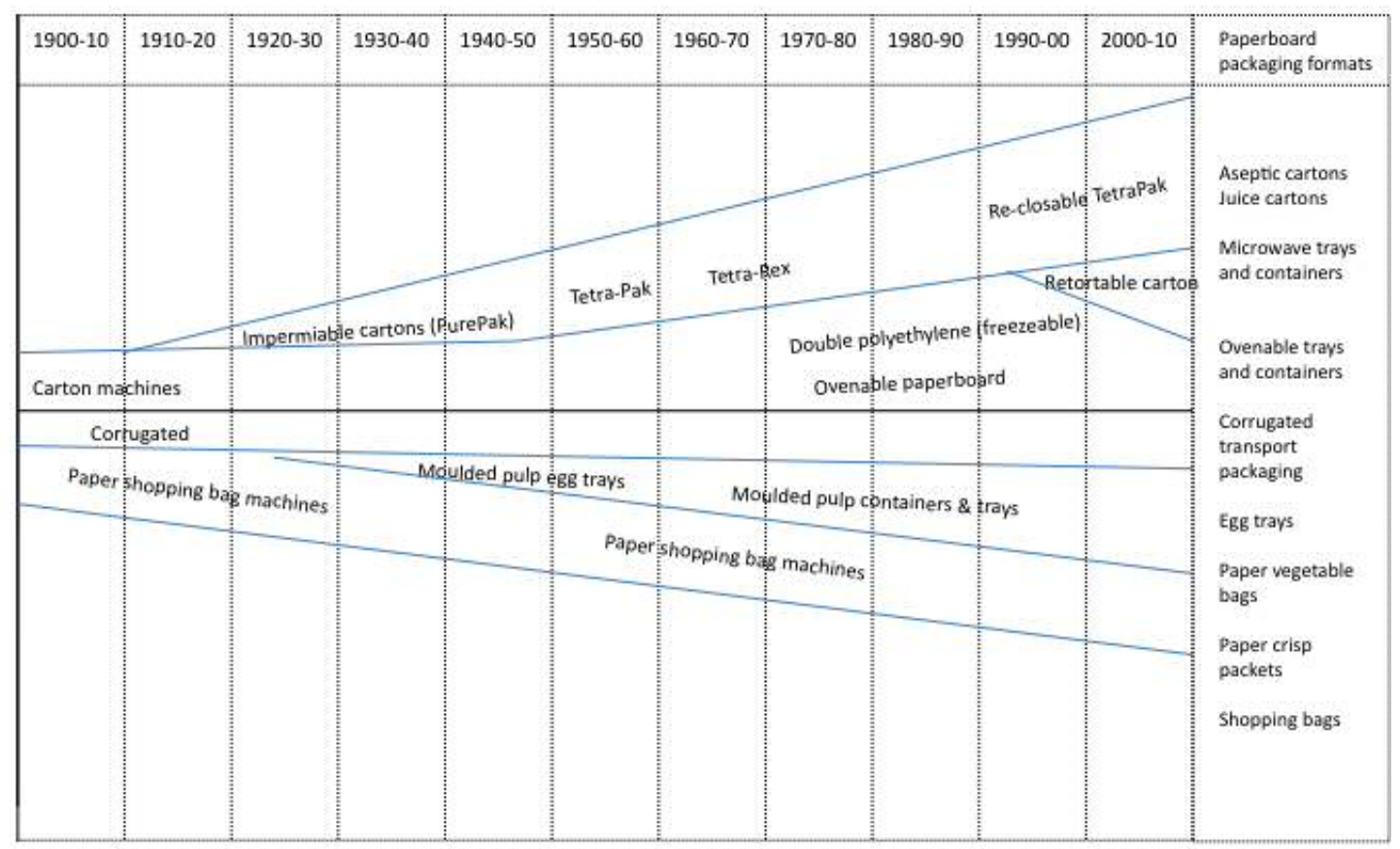


Table 1: Summary R\&D projects

\begin{tabular}{|c|c|c|}
\hline & Project A- Formable board & Project B- Milk pouch \\
\hline Focus of project & $\begin{array}{l}\text {-The development of a process for the } \\
\text { manufacturing of formable board }\end{array}$ & $\begin{array}{l}\text {-Developing a pouch and 'spine' with minimal } \\
\text { material usage, but sufficient structural rigidity }\end{array}$ \\
\hline Technical challenge & $\begin{array}{l}\text {-Establishing a manufacturing process for } \\
\text { different sizes of pressed shapes } \\
\text {-Waterproof coatings where required }\end{array}$ & $\begin{array}{l}\text {-Structural rigidity } \\
\text {-Food safety of drinks/milk product } \\
\text {-Material minimization }\end{array}$ \\
\hline Marketing challenge & -Identification likely target market/products & $\begin{array}{l}\text {-Identification of milk suppliers and retailers to } \\
\text { work with in testing the product } \\
\text {-Identification of a target market }\end{array}$ \\
\hline Key target markets identified & $\begin{array}{l}\text {-Razors \& blades } \\
\text {-Juice servings } \\
\text {-Confectionary } \\
\text {-Powdered beverages } \\
\text {-Teas } \\
\text {-Pill packets }\end{array}$ & $\begin{array}{l}\text {-Large \& small dairy } \\
\text {-Retailers } \\
\text {-Milk substitutes } \\
\text { *Wider target markets in longer term, as possible } \\
\text { adaption would allow potential to be a replacement } \\
\text { to pouches and other formats, but initially to be } \\
\text { targeted at milk as a high volume product. }\end{array}$ \\
\hline Key competing products & $\begin{array}{l}\text {-Rigid Plastic Containers } \\
\text {-Pouches } \\
\text {-Paperboard boxes }\end{array}$ & $\begin{array}{l}\text {-Aseptic cartons } \\
\text {-PET bottles } \\
\text {-Milk bags }\end{array}$ \\
\hline Partners/desired partnerships & $\begin{array}{l}\text {-Formable board supplier } \\
\text {-Desire to work with a FMCG firm to share } \\
\text { investment in process }\end{array}$ & -Desire to work with retailers \& milk suppliers \\
\hline Time project had been running & -Five years & -Four years \\
\hline Key investments to date & $\begin{array}{l}\text {-Investments in production machinery to } \\
\text { form board }\end{array}$ & $\begin{array}{l}\text {-Test lines to produce bag, spine, and to insert the } \\
\text { spine in bag } \\
\text {-Small tests in filling }\end{array}$ \\
\hline
\end{tabular}


Table 2: Summary of the problems highlighted, their characteristics, and how each forms a barrier to $R \& D$

\begin{tabular}{|c|c|c|}
\hline Barrier & Characteristics & Cause of Barrier \\
\hline (i) Costs & $\begin{array}{l}\text {-High capital equipment cost: any change will } \\
\text { require substantial investment } \\
\text {-High capital equipment costs/investments } \\
\text {-Unit cost increases affect margins, impacting on } \\
\text { change } \\
\text {-Incremental and exploitative focus of innovation }\end{array}$ & $\begin{array}{l}\text {-Cost avoidance } \\
\text {-Sunk investments } \\
\text {-Production line staff can lead to } \\
\text { further avoidance of changes } \\
\text {-Focus on margins and } \\
\text { incremental change }\end{array}$ \\
\hline (ii) Emergence of powerful buyers & $\begin{array}{l}\text {-Commodity product means that buyers are } \\
\text { charged with responsibility for packaging } \\
\text {-Act as the interface between the firms }\end{array}$ & $\begin{array}{l}\text {-Key decision maker } \\
\text {-Inhibit contact with key } \\
\text { decision makers } \\
\text {-Focus on costs }\end{array}$ \\
\hline $\begin{array}{l}\text { (iii) Insufficient Packaging } \\
\text { Champions }\end{array}$ & $\begin{array}{l}\text {-Lack of need to focus on packaging } \\
\text { development, as an undifferentiated part of the } \\
\text { offering. Leads to lack of need for internal staff } \\
\text { focusing on development. } \\
\text {-Lack of staff focusing on innovation } \\
\text {-Lack of staff to focus on collaboration } \\
\text {-Fail to see supplier's potential contribution } \\
\text {-Lack of packaging absorptive capacity }\end{array}$ & $\begin{array}{l}\text {-Lack of focus on packaging \& } \\
\text { opportunities } \\
\text {-No desire to work with } \\
\text { suppliers/personnel managing } \\
\text { supplier networking }\end{array}$ \\
\hline (iv) Language/Definitional Issues & $\begin{array}{l}\text {-This results in the only staff being left internally } \\
\text { focused on specific elements of the packaging (e.g. } \\
\text { design, graphics), and no one with a focus or } \\
\text { understanding of technological development } \\
\text {-Overlook packaging opportunities beyond } \\
\text { superficial level, with lack of awareness that they } \\
\text { are doing so due to different understanding of } \\
\text { packaging development }\end{array}$ & $\begin{array}{l}\text {-No focus on } \\
\text { development/innovation } \\
\text {-Lack of technical focus leads to } \\
\text { different meaning of } \\
\text { 'development' (e.g. marketing, } \\
\text { design, cost) }\end{array}$ \\
\hline (v) Supply Chain Position & $\begin{array}{l}\text {-Far away end customer } \\
\text {-Far away from distribution chain } \\
\text {-Lack of collaboration between supply chain } \\
\text { partners }\end{array}$ & $\begin{array}{l}\text {-Lack of access to data from } \\
\text { downstream supply chain } \\
\text { members }\left(2^{\text {nd }}, 3^{\text {rd }} \text { tier, and }\right. \\
\text { below) } \\
\text {-Lack of access to consumer } \\
\text { data }\end{array}$ \\
\hline
\end{tabular}




\section{Appendix 1}

Table 3: Summary of interviewees throughout the research period

\begin{tabular}{|c|c|c|c|c|}
\hline Interviewee & Job Role & Organisation & \begin{tabular}{|l|} 
No. of \\
Interviews
\end{tabular} & Role \\
\hline P1 & $\begin{array}{l}\text { Technical services } \\
\text { director }\end{array}$ & Case organisation & 2 & $\begin{array}{l}\text { Senior to Head of R\&D, as R\&D falls within } \\
\text { technical services. Therefore had an overview of } \\
\text { R\&D department, and its funding \& issues. }\end{array}$ \\
\hline P2 & Head of R\&D & Case organisation & 12 & $\begin{array}{l}\text { Overview of R\&D department, collaboration with } \\
\text { suppliers, customer meetings \& networking where } \\
\text { possible }\end{array}$ \\
\hline P3 & $\begin{array}{l}\text { Sales manager for } \\
\text { retailers (own } \\
\text { brand) }\end{array}$ & Case organisation & 3 & $\begin{array}{l}\text { Manager of sales to retailers, and suppliers, for own } \\
\text { branded products. This provided an overview of sales } \\
\text { to each of the four major UK retailers. }\end{array}$ \\
\hline P4 & $\begin{array}{l}\text { Sales manager for } \\
\text { branded clients }\end{array}$ & Case organisation & 2 & Managed two accounts to branded companies \\
\hline P5 & $\begin{array}{l}\text { Sales manager for } \\
\text { individual client- } \\
\text { FMCG \& OTC } \\
\text { Pharmaceuticals }\end{array}$ & Case organisation & 2 & $\begin{array}{l}\text { Managed the account for a single client, with on site } \\
\text { visits to production facilities on a regular basis }\end{array}$ \\
\hline P6 & $\begin{array}{l}\text { Design member of } \\
\text { R\&D team }\end{array}$ & Case organisation & 2 & $\begin{array}{l}\text { Managed the design of packaging for clients that } \\
\text { approached the firm with a brief }\end{array}$ \\
\hline P7 & Marketing Manager & Case organisation & 1 & $\begin{array}{l}\text { Overview of marketing plans, product plans, and } \\
\text { customer relationships }\end{array}$ \\
\hline P8 & $\begin{array}{l}\text { R\&D: Technical } \\
\text { manager/engineer }\end{array}$ & Case organisation & 1 & $\begin{array}{l}\text { Technical development, including working with } \\
\text { suppliers and customers where necessary/possible }\end{array}$ \\
\hline P9 & $\begin{array}{l}\text { Head of Marketing } \\
\text { in key supplier and } \\
\text { collaborative } \\
\text { partner }\end{array}$ & $\begin{array}{l}\text { Case organization and } \\
\text { key supplier }\end{array}$ & 3 & $\begin{array}{l}\text { This member of staff worked jointly for the case } \\
\text { firm, as well as one of its suppliers, and an industry } \\
\text { body for the paperboard packaging industry. }\end{array}$ \\
\hline P10 & $\begin{array}{l}\text { Industry body } \\
\text { representative \& } \\
\text { partner to firm }\end{array}$ & Industry body & 3 & $\begin{array}{l}\text { This interviewee worked for a packaging industry } \\
\text { body, but also worked closely with the case firm. }\end{array}$ \\
\hline P11 & $\begin{array}{l}\text { Technical } \\
\text { packaging manager } \\
\text { in retailer }\end{array}$ & $\begin{array}{l}\text { Leading UK retailer } \\
\text { [top 5] }\end{array}$ & 3 & $\begin{array}{l}\text { Involved in managing the packaging production line } \\
\text { and process improvement, some involvement in NPD } \\
\text { ad-hoc }\end{array}$ \\
\hline P12 & $\begin{array}{l}\text { Head of packaging } \\
\text { design }\end{array}$ & $\begin{array}{l}\text { Largest global food } \\
\text { and drinks product } \\
\text { manufacturer and } \\
\text { brand owner }\end{array}$ & 3 & $\begin{array}{l}\text { Involved in packaging design and manager of the } \\
\text { packaging design process (the approach to packaging } \\
\text { was design driven) }\end{array}$ \\
\hline P13 & $\begin{array}{l}\text { Head of packaging } \\
\text { and reprographics at } \\
\text { Retailer }\end{array}$ & $\begin{array}{l}\text { Own brand food and } \\
\text { drinks operations of a } \\
\text { top } 5 \text { retailer }\end{array}$ & 2 & $\begin{array}{l}\text { Head of a 'packaging team and reprographics team', } \\
\text { reporting to each key category manager within the } \\
\text { retailer }\end{array}$ \\
\hline P14 & Production manager & $\begin{array}{l}\text { Local dairy supplier } \\
\text { to supermarket }\end{array}$ & 1 & $\begin{array}{l}\text { Responsible for marketing decisions and role in } \\
\text { packaging decision making }\end{array}$ \\
\hline P15 & $\begin{array}{l}\text { Technical } \\
\text { packaging manager }\end{array}$ & $\begin{array}{l}\text { Top three world foods } \\
\text { (snack foods and soft } \\
\text { drinks) manufacturer } \\
\text { \& brand owner }\end{array}$ & 1 & $\begin{array}{l}\text { Individual bought into the NPD team as required, } \\
\text { with a variable role in packaging technical decisions, } \\
\text { including materials and format choices. }\end{array}$ \\
\hline
\end{tabular}




\begin{tabular}{|c|c|c|c|c|}
\hline P16 & Marketing manager & $\begin{array}{l}\text { Market leading } \\
\text { supplier and brand } \\
\text { owner of milk } \\
\text { alternative products } \\
\text { (inc. soya and other } \\
\text { alternatives) }\end{array}$ & 1 & $\begin{array}{l}\text { Marketing manager for branded milk alternative } \\
\text { company }\end{array}$ \\
\hline P17 & $\begin{array}{l}\text { Long range } \\
\text { planning manager }\end{array}$ & $\begin{array}{l}\text { Global provider of } \\
\text { ingredients and } \\
\text { solutions to the food, } \\
\text { beverage and other } \\
\text { markets. }\end{array}$ & 1 & $\begin{array}{l}\text { Long term planning manager for ingredients supplier } \\
\text { (both B2B and consumer ingredients) }\end{array}$ \\
\hline P18 & $\begin{array}{l}\text { Independent } \\
\text { packaging } \\
\text { consultant and } \\
\text { representative for } \\
\text { industry body }\end{array}$ & $\begin{array}{l}\text { Small packaging } \\
\text { consultancy and } \\
\text { packaging materials } \\
\text { suppliers industry } \\
\text { body }\end{array}$ & 2 & $\begin{array}{l}\text { Independent packaging consultant. Also had an } \\
\text { overview of issues within packaging and raw } \\
\text { materials industries }\end{array}$ \\
\hline P19 & $\begin{array}{l}\text { Packaging buyer } \\
\text { and reduction } \\
\text { manager }\end{array}$ & $\begin{array}{l}\text { Retailer in top three in } \\
\text { UK, in terms of } \\
\text { market share. }\end{array}$ & 1 & $\begin{array}{l}\text { Buyer responsible for managing packaging used by } \\
\text { suppliers, and ensuring accordance to the company's } \\
\text { environmental commitments. Played key role in } \\
\text { implementation environmental strategy, and } \\
\text { purchasing cost reduction. }\end{array}$ \\
\hline $\mathrm{P} 20$ & Packaging manager & $\begin{array}{l}\text { Retailer in top three in } \\
\text { UK, in terms of } \\
\text { market share. }\end{array}$ & 2 & $\begin{array}{l}\text { Responsible for monitoring suppliers purchasing of } \\
\text { packaging, to ensure appropriate company standards } \\
\text { are met. }\end{array}$ \\
\hline $\mathrm{P} 21$ & Marketing manager & $\begin{array}{l}\text { Leading UK supplier } \\
\text { of branded cosmetics. }\end{array}$ & 2 & $\begin{array}{l}\text { Key decision maker for packaging, working } \\
\text { alongside a packaging technical manager that was } \\
\text { involved in production line decisions and changes. }\end{array}$ \\
\hline P22 & Marketing manager & $\begin{array}{l}\text { Own brand and } \\
\text { branded biscuits } \\
\text { supplier. }\end{array}$ & 1 & $\begin{array}{l}\text { Key role in packaging decision-making. Particular } \\
\text { interest/involvement in design, graphics, and label } \\
\text { changes. }\end{array}$ \\
\hline $\mathrm{P} 23$ & $\begin{array}{l}\text { Director of } \\
\text { Innovation }\end{array}$ & $\begin{array}{l}\text { International } \\
\text { pharmaceutical } \\
\text { company }\end{array}$ & 1 & $\begin{array}{l}\text { Overview of R\&D, including packaging related } \\
\text { projects and activities. }\end{array}$ \\
\hline P24 & $\begin{array}{l}\text { Head consultant for } \\
\text { food industry body }\end{array}$ & $\begin{array}{l}\text { Food industry body } \\
\text { and research company }\end{array}$ & 1 & $\begin{array}{l}\text { Overview of sector and point of reference for some } \\
\text { FMCG firms. }\end{array}$ \\
\hline
\end{tabular}

